\title{
Özel sağlık kuruluşlarında hizmet alan bireylerin kalite algılarının belirlenmesi: Bir SERVPERF uygulaması
}

\author{
Cemal SEZER ${ }^{a}$, Ayhan DURMUŞ ${ }^{b *}$, Melih BEBiKc $^{c}$ \\ a Sakarya Üniversitesi, Sağlık Yönetimi, e posta: csezer@sakarya.edu.tr, Orcid: 0000-0002-5883-0993 \\ b* Sakarya Üniversitesi, Sağlık Yönetimi, e posta: ayhandurmus@sakarya.edu.tr, Orcid: 0000-0001-8362-2769 \\ c Eskişehir Özel Ümit Hastanesi, İnsan Kaynakları Birimi, e posta: emelihbk@gmail.com, Orcid: 0000-0002-6470-6147
}

\section{MAKALE BiLGILERi}

Araştırma Makalesi

Geliş Tarihi 6 Kasım 2020

Revizyon 18 Kasım 2020

Kabul tarihi 18 Kasım

2020

\section{Özet}

Bu çalışmada, özel sağlık kuruluşundan hizmet almış bireylerin sağlık hizmetine yönelik hizmet kalitesi algısını belirlemeyi amaçlamaktadır. Çalışmanın evrenini Eskişehir'deki bir özel hastaneden hizmet almış, 18 yaşından büyük ve akıl sağlığı yerinde kişiler olușturmaktadır. Calıșmada rastgele örneklem yöntemi kullanılmıștır. Veriler, hastalarla yüz yüze soru formu (anket) yöntemi ile toplanmış; 212 adet kullanılabilir anket formu elde edilmiştir. Veri toplamada, Cronin ve Taylor (1992) tarafından geliştirilen ve beş alt boyuttan oluşan SERVPERF Ölçeği kullanılmıştır. Verilerin analizinde tanımlayıcı istatiksel yöntemler, $t$ testi, One Way Anova testi, güvenirlik analizi, korelasyon analizi kullanılmıştır. Çalışmanın bulgularına göre, ölçeğin alt boyutlarına yönelik cronbach's alfa değerleri 0,74 ile 0,87 arasında değişmektedir. Ölçeğe ilişkin değer ise 0,91'dir. Hizmet kalitesi ölçeği ile alt boyutlar arasında yüksek düzeyde anlamlı ilişki vardır. Çalışmanın amacına ilişkin olarak gerçekleştirilen fark analizi bulgularına göre, katılımcıların hizmet kalitesi algıları ile sosyo-demografik değişkenler arasında farklıık tespit edilmemiştir. Buna göre, hizmet kalitesi algısı düzeylerinin yüksek olduğu söylenebilir. Sonuç olarak, söz konusu hastanenin, hastaların aldıkları hizmetten ne düzeyde memnun oldukların dikkate alarak yapı ve süreçlerini izlemesi ve biçimlendirmesi gerekmektedir. Çünkü günümüzde sağlık hizmetlerinin hasta merkezl olarak sunulması bu durumu kaçınılmaz hale getirmektedir. Böylelikle, sağıık kuruluşunun kaliteli hizmet sunması hem etkinlik ve verimliliği artırmış olacak hem de bireylere yararlar sağlamış olacaktır.

Anahtar Kelimeler: Sağıık; hizmet; kalite; kalite algısı.

\section{Determining the quality perception of individuals receiving services in private healthcare institutions: A SERVPERF application}

\section{ARTICLE INFO}

Research Article

Received 6 November 2020

Received in revised form

18 November 2020

Accepted 18 November 2020

\section{Abstract}

According to this study, it is aimed to measure the service quality perceptions of individuals who have received services from private health care institutions. The population of the study consisted of people aged over 18 years who had received services from a private hospital in Eskissehir. Random sampling method was used in the study. Data were collected by face-to-face questionnaire method and 212 usable questionnaires were obtained. The data were collected by SERVPERF Scale, which was developed by Cronin and Taylor (1992). Descriptive statistical methods, t test, One Way Anova test, reliability analysis, correlation analysis were used in the analysis of the data. According to the findings of the study, Cronbach's Alpha values for the sub-dimensions of the scale ranged from 0.74 to 0.87 . The value of the scale is 0.91 . There is a high level of significant relationship between service quality scale and sub-dimensions. According to the difference analysis findings related to the purpose of the study, no difference was found between the participants' perception of service quality and sociodemographic variables. Accordingly, it can be said that service quality perception levels are high. As a result, the hospital in question needs to monitor and shape its structures and processes, taking into account the extent to which patients are satisfied with the service they receive. Because the provision of health services in a patientcentered manner makes this situation inevitable. In this way, the quality of service provided by the health institution will not only increase efficiency and productivity but will also provide benefits to individuals.

Key Words: Health, service, quality, quality perception

\section{Giriş}

Hizmet sektöründe kalite olgusu, imalat sektörünün aksine, değişken, göreceli ve çoğu kez nesnel olmayan değerlendirmelerin ötesine geçemeyen tartışmalı bir konudur. İnsan yaşamıyla doğrudan ilgili olan sağlık hizmetlerinde ise durum daha da karmaşık olup, sağlık hizmeti paydaşları olan; sunucuların, tüketicilerin (hastaların), satın alıcıların ve tedarikçilerin özellikleri ve öncelikleri tarafından etkilenen sistemik bir karaktere sahiptir. Dolayısıyla sağlık hizmetlerinde kalite, tüm sağlık hizmeti paydaşlarının iş birliği ve etkileşimi sonucunda ortaya çıkan bütüncül bir olgu ve değerlendirmedir. (Spath, 2009: 5; Sezer, 2018: 991).

Sağlık sektöründe hizmet kalitenin iyileştirilmesi ve kaliteli sağlık hizmetlerinin sunumu, bireylerin sağlığı ve refahı açısından önemli etkilere sahipken, toplumun sağlık durumu üzerinde de olumlu etkiler yaratmaktadır. Bu durum, hem ülke ekonomisine hem de topluma yarar sağlamaktadır (Rezaei et al., 2018: 1). Ayrıca sağlık hizmetlerinin kalitesi, sağlık hizmeti sunucuları açısından iyileştirilmesi gereken süreçlerin ve hizmetlerin belirlenmesinde de faydalı olmaktadır (Pakdil ve Harwood, 2005). Alan yazında sağlık hizmetlerinin kalitesine ilişkin sıklıkla atıf alan çok sayı ve çeşitte tanımlar bulunduğu; bu tanım ve tanımlamaların sürekli geliştiği söylenebilir. Örneğin, ABD Tıp Enstitüsü tarafından sağlık hizmetlerinin kalitesi, "bireylere ve topluma sunulan sağlık hizmetlerinin, arzulanan sağlık sonuçlarına ulaşma olasılığını artırma ve şimdiki profesyonel bilgiyle tutarlı olma derecesi” olarak tanımlanmaktadır (Aktaran Kaya, 2014:11). AMA (American Medical Association- Amerikan Tıp Derneği) 1984 yılında yüksek kaliteli hizmeti, "yaşam kalitesini ve/veya süresini iyileştirmeye veya sürdürmeye sürekli olarak katkıda bulunan hizmet" şekilde tanımlamıştır. Donabedian (1980) ise, sağlık hizmetlerinde kaliteyi, "hizmet sürecinin bütün kısımlarındaki beklenen kazançlar ve kayıplar dengesi hesaba katıldıktan sonra, hastanın iyilik halinin kapsamlı bir ölçüsünü en üst düzeye çıkarması beklenen hizmet" şeklinde tanımlamaktadır.

Sağlık hizmetlerinde bütüncül bir kaliteden söz etmek ve eksik olmayan bir yargıya varabilmek için, tüm sağlık hizmeti paydaşlarının iş birliği ve etkileșimini yansıtan ve güncel profesyonel sağlık/ tıp bilgileriyle tutarlı olan sonuçların ortaya çıkarılması gerekir. Ancak sağlık hizmeti kalitesiyle ilgili akademik çalışmaların çoğunda genellikle, hizmet sunucuları veya hastaların görüşlerine başvurulduğu görülmektedir. Sağlık hizmetlerinin kalitesi hakkında hasta görüşlerine başvurmanın özel sağlık sektörü bağlamında makul ve anlaşılabilir gerekçeleri bulunmaktadır. Çünkü özel sağlık kuruluşlarının yaygınlaşması ile birlikte, sağlık sektöründe rekabetin yolu açılmış ve sağlık hizmetleri kalitesinin tanımlanmasında hastaların tercih ve görüşleri, daha somut bir ifade ile hasta memnuniyeti 
önemli bir parametre haline gelmiştir. Özel sağlık sektöründe/ piyasasında hasta dolaşımının akraba, arkadaş, sosyal medya ve profesyonel çevrelerden gelen önerilerden/ tavsiyelerden etkilendiği artık bir sır değildir. Aldığı sağlık hizmetlerinin kalitesinden memnun olarak toplumsal hayata dönen hastaların tavsiyesi ile söz konusu kuruluşları tercih edenlerin sayısında artış olduğu da bilinmektedir. Bu bağlamda özel sağık kuruluşları, bütünsel sağık kalitesinin bir öğesi olan hasta memnuniyetine daha fazla önem atfetmekte ve hizmet sundukları hastaların memnuniyet düzeylerini yüksek tutarak, hasta tavsiyesi ile başka bireylerin kendilerini tercih etmelerini sağlamaya çalışmaktadırlar. Dolayısıyla sağlık hizmeti paydaşlarının iş birliği ve etkileşimi sonucunda ortaya çıkan bir olgu olan sağlık hizmetleri kalitesinin, sunulan hizmetin asıl tüketicisi olan hasta açısından da tanımlanması gereği ortaya çıkmaktadır. Buna göre sağlık hizmetlerinin kalitesi, (hastanın) kendisine sunulan ya da kendisi üzerinde uygulanan hizmeti nasıl gördüğüne bağlı olarak biçimlenen nesnel olmayan bir değerlendirme ve algı şeklinde tanımlanabilir. Bu nedenle hasta gözüyle sağlık hizmeti kalitesi yerine, algılanan sağlık hizmeti kalitesinden söz etmek daha uygundur (Sezer, 2018: 991).

Sağlık sektöründe algılanan hizmet kalitesi, genellikle Donabedian (1966) 'ın yapı, süreç ve sonuç paradigması çerçevesinde ve SERVQUAL (Parasuraman et al., 1985) modeli ile belirlenmektedir. SERVQUAL, sağlık sektöründe kullanılan en yaygın ölçüm aracıdır. Ölçek beş boyuttan (güvence, empati, güvenilirlik, cevap verebilirlik ve somutluk/fiziksel varlık) oluşmakla birlikte, SERVQUAL modeline göre hizmet kalitesi, bireyin hizmet öncesi beklentisi ile hizmeti aldıktan sonraki deneyimi arasındaki fark sonucunda ortaya çıkmaktadır (Parasuraman et al., 1985: 47). SERVQUAL modeline alternatif olarak Cronin ve Taylor (1992) tarafından SERVPERF modeli geliştirilmiştir. Bu model de hizmet kalitesinin değerlendirilmesini beş boyutta (güvence, empati, güvenilirlik, cevap verebilirlik ve somutluk/fiziksel varlık) ele almaktadır. Cronin ve Taylor (1992) öncelikle SERVQUAL modelini eleştirmiş; SERVPERF modelinin hizmet kalitesinin belirlenmesinde daha etkili; boyutsallığı, güvenilirliği ve geçerliliğinin daha iyi olduğunu belirtmişlerdir. Ayrıca bu modelin daha fazla hizmet kalitesi çeşitliliğini ele aldığını da ileri sürmüşlerdir. SERVPERF modeli hizmet kalitesini, SERVQUAL modelinin beklenen hizmet ile algılanan hizmet arasındaki farka dayalı belirlenmesi yerine sadece hizmet performansına dayalı olarak hizmet kalitesinin belirlenmesini destelemektedir. Yani SERVQUAL modelinde dikkate alınan bireyin beklentileri SERVPERF modelinde dikkate alınmamaktadır. Sağlık alanındaki çalışmalarda da SERVQUAL modeli eleştirilmekle birlikte, hizmet kalitesinin beş boyutu sağlık sektöründe özel uygulama alanlarına (birinci basamak, acil servis gibi) bağlı olarak farklılık gösterebilmektedir (Strawderman ve Koubek, 2006). Aynı zamanda hizmet kalitesini belirlemek için algılar ve beklentiler arasındaki farkın kullanılması (yani, boşluk ölçümü) sağlık sektöründe uygunsuz olarak değerlendirilmektedir. Çünkü pek çok bireyin tıbbi ziyaretten önce sağlık hizmetleri beklentisi bulunmamaktadır (Boulding et al., 1993:24; Taylor ve Cronin, 1994: 42). Bu çalışmada, bir özel sağlık kuruluşundan hizmet alan bireylerin almış oldukları sağık hizmetine ilişkin kalite algıları SERVPERF modeliyle belirlenmeye çalışılıışır.

\section{Yöntem}

Bu çalışmada, özel sağlık kuruluşundan hizmet almış bireylerin sağlık hizmetine yönelik algılarının belirlenmesi amaçlanmaktadır. Çalışmanın evrenini Eskişehir'deki bir özel hastaneden hizmet almış, 18 yaşından büyük ve akıl sağlığı yerinde kişiler oluşturmaktadır. Çalışmada rastgele örneklem yöntemi kullanılmışır. Çalışmada kullanılan model aşağıdaki gibi tasarlanmıştır (Şekil 1).

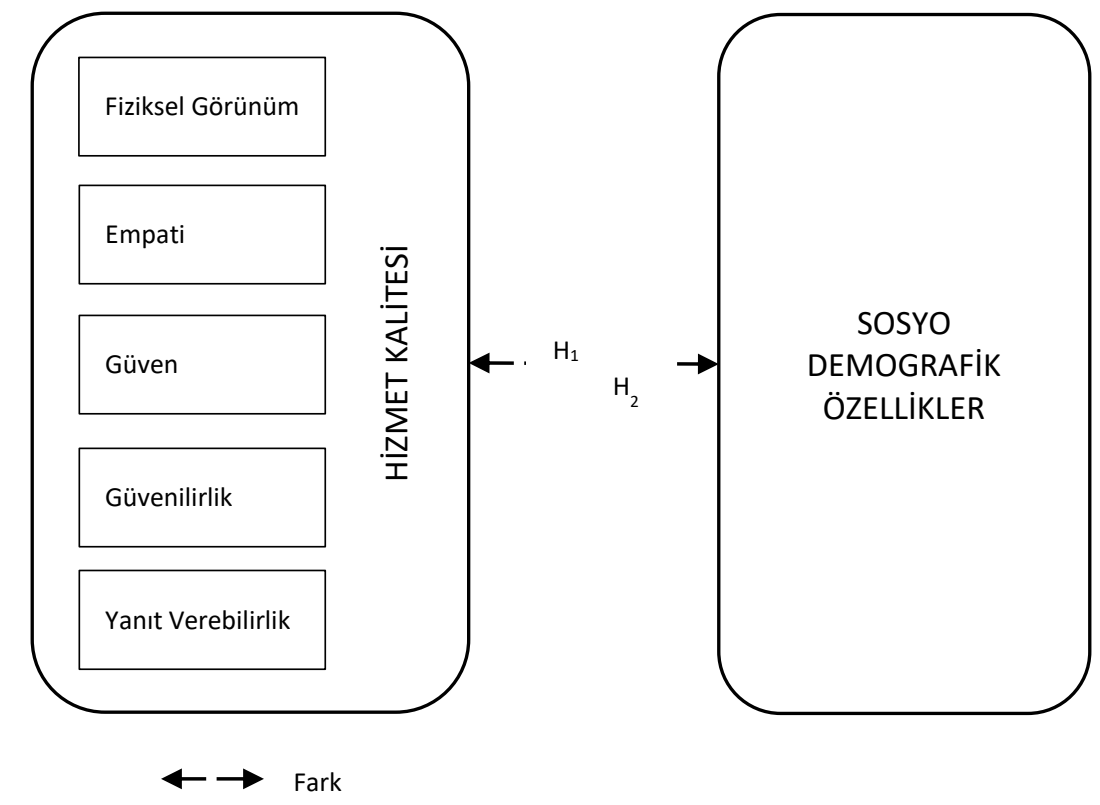

Şekil 1. Çalışmanın modeli

Veri toplamada, Cronin ve Taylor (1992) tarafından geliştirilen ve beş alt boyuttan oluşan SERVPERF Ölçeği kullanılmıştır. Veriler, hastalarla yüz yüze soru formu (anket) yöntemi ile toplanmış; 212 adet kullanılabilir anket formu elde edilmiştir. Çalışmanın amacına uygun olarak tasarlanan Şekil 1'deki modelden yararlanılarak aşağıdaki hipotezler geliştirilmiştir.

$\mathrm{H}_{1}$ : Özel sağlık kuruluşundan hizmet alan bireylerin hizmete ilişkin kalite algıları yüksek düzeydedir.

$\mathrm{H}_{2}$ : Özel sağlık kuruluşundan hizmet alan bireylerin hizmete ilişkin kalite algıları sosyo-demografik özelliklere göre farklıdır.

Verilerin analizinde tanımlayıcı istatiksel yöntemler, $t$ testi, One Way Anova testi, güvenirlik analizi, korelasyon analizi kullanılmıştır. Veriler \%95 güven aralığında, $p<0,05$ anlamlıık düzeyinde analiz edilmiştir. Ölçekler ve boyutlarına ait ortalamaları değerlendirmek için ise, kullanılan formül ve aralıklar şöyledir: Aralıkların eşit olduğu varsayıımış ve aritmetik ortalamalar için puan aralığı katsayısı 0.80 olarak hesaplanmıştır [Puan Aralığı = (En Yüksek Değer-En Düşük Değer) $/ 5=4 / 5=0,80]$. Bu değer cevap kodlarının en düşüğü olan 1,00'a, ardışık olarak sonraki değerlere eklenerek değerlendirme aralıkları elde edilmiştir. Buna göre aritmetik ortalamaları değerlendirme aralıkları (Çınar, 2010: 271): "1,00-1,80 çok düşük; 1,81-2,60 düşük; 2,61-3,40 orta; 3,41-4,20 yüksek; 4,215,00 çok yüksek" şeklindedir.

Saha araştırması yapılmadan önce Sakarya Üniversitesi etik kurulundan (06/03/20190 tarih ve E.3259) gerekli izin ve onaylar alınmıştır. Ayrıca, Çalışma Helsinki Bildirgesi'nin (2013) ilkelerine göre yürütülmüştür.

\section{Bulgular}

Çalışmaya katılan bireylerin sosyo demografik özelliklerine göre dağııımları Tablo 1'de yer almaktadır. Buna göre, katılımcıların \%54,2'si erkek ve \%45,8'i ise kadındır. Bireylerin \%60,4'ü 2000 lira ve üstü gelire ve \%40,6'sı ortaöğretim eğitimine sahiptir. Yaş dağılımlarına göre ise bireylerin yaşları oranı birbirlerine yakın dağııım göstermektedir. Bireylerin sağıık hizmetini almak için polikliniklerde bekledikleri süre 25 dakikanın altındadır. Ayrıca doktorun muayene için ayırdığı zamanının yeterli olduğunu ifade eden birey oranı \%94,3'tür ve bireylerin $\% 89,2$ 'si almış oldukları hizmeti tavsiye edeceğini belirtmektedir. 
Tablo 1. Katılımcıların sosyo demografik özellikleri

\begin{tabular}{|c|c|c|c|c|c|c|c|}
\hline & & Sayı & Yüzde & & & Sayı & Yüzde \\
\hline \multirow{2}{*}{ Cinsiyet } & Kadın & 97 & 45,8 & \multirow{2}{*}{ Gelir Durumu } & $<2000 €$ & 84 & 39,6 \\
\hline & Erkek & 115 & 54,2 & & $\geq 2000 €$ & 128 & 60,4 \\
\hline \multirow{4}{*}{ Yaş } & $\leq 25$ yaş & 82 & 38,7 & \multirow{4}{*}{ Eğitim Durumu } & Illköğretim & 32 & 15,1 \\
\hline & $26-35$ & 47 & 22,2 & & Ortaöğretim & 86 & 40,6 \\
\hline & $36-45$ & 48 & 22,6 & & Önlisans & 35 & 16,5 \\
\hline & $\geq 46$ yaş & 35 & 16,5 & & Lisans & 59 & 27,8 \\
\hline \multirow{3}{*}{ Bekleme Süresi } & $5^{\prime}-15^{\prime}$ & 100 & 47,2 & \multirow{3}{*}{\multicolumn{4}{|c|}{$\begin{array}{l}\text { Katılımcıların \%94,3'ü muayene zamanı yeterli olduğunu; } \\
\text { \%89,2'si tavsiye ederim demiştir. }\end{array}$}} \\
\hline & $16^{\prime}-25^{\prime}$ & 94 & 44,3 & & & & \\
\hline & $26^{\prime}-35^{\prime}$ & 18 & 8,5 & & & & \\
\hline
\end{tabular}

Tablo 2'de SERVPERF ölçeğine ilişkin güvenilirlik ve ortalama değerler yer almaktadır. Buna göre, ölçeğin cronbach's alpha değeri 0,91 ve alt boyutlara ilişkin alpha değerleri 0,74-0,87 arasında değişmektedir. Ölçeğin orijinal çalışmasında ise güvenilirlik değeri 0,93 olarak hesaplanmıştır (Taylor ve Cronin, 1994: 39). Hizmet kalitesi ölçeğinin tamamına ait ortalama değer $4,12 \pm 0,34$ ve alt boyutlara ait ortalama değerler $4,01 \pm 0,48$ ile $4,22 \pm 0,43$ aralığında değişmektedir. Bu durumda ölçeğin hem güvenilir olduğunu hem de yüksek ortalama düzeyine sahip olduğunu söyleyebiliriz. Buna göre, $\mathrm{H} 1 \mathrm{hipotezi}$ kabul edilmiştir.

\begin{tabular}{lccc}
\multicolumn{4}{c}{ Tablo 2. SERVPERF ölçeğine ilişkin güvenilirlik ve ortalama değerler } \\
\hline & Cronbach's $\boldsymbol{\alpha}$ & Ortalama & Std. Sapma \\
\hline Fiziksel Görünüm & 0,74 & 4,12 & 0,42 \\
\hline Empati & 0,76 & 4,09 & 0,44 \\
\hline Güven & 0,78 & 4,22 & 0,43 \\
\hline Güvenilirlik & 0,77 & 4,01 & 0,48 \\
\hline Yanıt Verebilirlik & 0,87 & 4,14 & 0,52 \\
\hline Hizmet Kalitesi & 0,91 & 4,12 & 0,34
\end{tabular}

Hizmet kalitesi ve alt boyut arasındaki ilişkiyi belirlemek amacıyla gerçekleştirilen korelasyon analizi sonuçlarına göre, hizmet kalitesi ile alt boyutlar arasında pozitif yönlü güçlü ilişki olduğu saptanmıştır (Tablo3). Ayrıca ölçeğin alt boyutlarının kendi aralarında da ilişkinin olduğu görülmektedir.

\begin{tabular}{lccccc}
\multicolumn{6}{c}{ Tablo 3. SERVPERF ölçeğine ilişkin korelasyon analizi bulguları } \\
\hline & $\mathbf{1}$ & $\mathbf{2}$ & $\mathbf{3}$ & $\mathbf{4}$ & $\mathbf{5}$ \\
\hline Fiziksel Görünüm (1) & 1 & & & & \\
\hline Empati (2) &, $531^{* *}$ & 1 & & & \\
\hline Güven (3) &, $511^{* *}$ &, $622^{* *}$ & 1 & & \\
\hline Güvenilirlik (4) &, $408^{* *}$ &, $373^{* *}$ &, $443^{* *}$ & 1 & \\
\hline Yanıt Verebilirlik (5) &, $345^{* *}$ &, $491^{* *}$ &, $553^{* *}$ &, $299^{* *}$ & 1 \\
\hline Hizmet Kalitesi &, $746^{* *}$ &, $809^{* *}$ &, $820^{* *}$ &, $663^{* *}$ &, $722^{* *}$ \\
\hline **. 0,01 düzeyinde anlaml korelasyon & & &
\end{tabular}

Tablo 4'te hizmet kalitesi ve alt boyutlarının cinsiyet değişkeni ile arasında anlamlı farklılığı tespit etmek amacıyla yapılan t testi sonuçları yer almaktadır. Tabloya göre, bireylerin cinsiyetleri ile hizmet kalitesi ve alt boyutları arasında istatistiksel açıdan anlamlı farklılık bulunmamıştır.

Tablo 4. Cinsiyet değişkenine göre T testi sonuçları

\begin{tabular}{|c|c|c|c|c|c|c|}
\hline Cinsiyet & & Sayı & Ort. & S.S. & $\mathrm{t}$ & $p$ \\
\hline \multirow{2}{*}{ Fiziksel Görünüm } & Kadın & 97 & 4,12 & 0,47 & \multirow{2}{*}{,- 188} & \multirow{2}{*}{,851 } \\
\hline & Erkek & 115 & 4,13 & 0,38 & & \\
\hline \multirow{2}{*}{ Empati } & Kadın & 97 & 4,05 & 0,46 & \multirow{2}{*}{$-1,092$} & \multirow{2}{*}{ 276 } \\
\hline & Erkek & 115 & 4,12 & 0,42 & & \\
\hline \multirow{2}{*}{ Güven } & Kadın & 97 & 4,20 & 0,44 & \multirow{2}{*}{,- 670} & \multirow{2}{*}{,504 } \\
\hline & Erkek & 115 & 4,24 & 0,42 & & \\
\hline \multirow{2}{*}{ Güvenilirlik } & Kadın & 97 & 4,00 & 0,51 & \multirow{2}{*}{,- 396} & \multirow{2}{*}{ 692 } \\
\hline & Erkek & 115 & 4,03 & 0,45 & & \\
\hline \multirow{2}{*}{ Yanıt Verebilirlik } & Kadın & 97 & 4,16 & 0,53 & \multirow{2}{*}{,498 } & \multirow{2}{*}{ 619 } \\
\hline & Erkek & 115 & 4,13 & 0,52 & & \\
\hline
\end{tabular}




\begin{tabular}{lllllll}
\hline \multirow{3}{*}{ Hizmet Kalitesi } & Kadın & 97 & 4,11 & 0,38 & & \multirow{2}{*}{ 634 } \\
\cline { 2 - 6 } & Erkek & 115 & 4,13 & 0,31 & & \\
\hline
\end{tabular}

Bireylerin gelir durumu ile hizmet kalitesi ve alt boyutları arasındaki farklıı̆̆ belirlemek amacıyla gerçekleştirilen analiz sonuçlarına göre (Tablo 5), gelir durumu değişkeni ile ölçek ve alt boyutları arasında anlamlı farklılık saptanmamıştır.

Tablo 5. Gelir durumu değişkenine göre T testi sonuçları

\begin{tabular}{|c|c|c|c|c|c|c|}
\hline \multicolumn{2}{|c|}{ Gelir Durumu } & Sayı & Ort. & S.S. & $\mathrm{t}$ & $\mathrm{p}$ \\
\hline \multirow{2}{*}{ Fiziksel Görünüm } & $<2000 \mathrm{TL}$ & 84 & 4,09 & 0,46 & \multirow{2}{*}{$-1,000$} & \multirow{2}{*}{,318 } \\
\hline & $\geq 2000 \mathrm{TL}$ & 128 & 4,14 & 0,40 & & \\
\hline \multirow{2}{*}{ Empati } & $<2000 \mathrm{TL}$ & 84 & 4,04 & 0,42 & \multirow{2}{*}{$-1,441$} & \multirow{2}{*}{ 151 } \\
\hline & $\geq 2000 \mathrm{TL}$ & 128 & 4,12 & 0,44 & & \\
\hline \multirow{2}{*}{ Güven } & $<2000 \mathrm{TL}$ & 84 & 4,19 & 0,46 & \multirow{2}{*}{,- 844} & \multirow{2}{*}{,400 } \\
\hline & $\geq 2000 \mathrm{TL}$ & 128 & 4,24 & 0,41 & & \\
\hline \multirow{2}{*}{ Güvenilirlik } & $<2000 \mathrm{TL}$ & 84 & 4,05 & 0,53 & \multirow{2}{*}{,887 } & \multirow{2}{*}{,376 } \\
\hline & $\geq 2000 \mathrm{TL}$ & 128 & 3,99 & 0,44 & & \\
\hline \multirow{2}{*}{ Yanıt Verebilirlik } & $<2000 \mathrm{TL}$ & 84 & 4,08 & 0,46 & \multirow{2}{*}{$-1,410$} & \multirow{2}{*}{ 160 } \\
\hline & $\geq 2000 \mathrm{TL}$ & 128 & 4,18 & 0,56 & & \\
\hline \multirow{2}{*}{ Hizmet Kalitesi } & $<2000 \mathrm{TL}$ & 84 & 4,09 & 0,37 & \multirow{2}{*}{$-1,033$} & \multirow{2}{*}{,303 } \\
\hline & $\geq 2000 \mathrm{TL}$ & 128 & 4,14 & 0,32 & & \\
\hline
\end{tabular}

Tablo $6^{\prime}$ da bireylerin yaş değişkeni ile hizmet kalitesi ve alt boyutları arasındaki farklılığı ortaya çıkarmak amacıyla yapılan ANOVA testi sonuçlarına göre, bireylerin yaş değişkeni ile ölçek ve alt boyutları arasında anlamlı farklılık tespit edilmemiştir.

Tablo 6. Yaş değişkenine göre ANOVA testi sonuçları

\begin{tabular}{|c|c|c|c|c|c|c|}
\hline Yaş & & Sayı & Ort. & S.S. & $\mathrm{F}$ & $p$ \\
\hline \multirow{4}{*}{ Fiziksel Görünüm } & $\leq 25$ yaş & 82 & 4,14 & 0,37 & \multirow{4}{*}{1,300} & \multirow{4}{*}{ 275 } \\
\hline & $26-35$ & 47 & 4,07 & 0,30 & & \\
\hline & $36-45$ & 48 & 4,19 & 0,49 & & \\
\hline & $\geq 46$ yaş & 35 & 4,03 & 0,55 & & \\
\hline \multirow{4}{*}{ Empati } & $\leq 25$ yaş & 82 & 4,10 & 0,37 & \multirow{4}{*}{1,073} & \multirow{4}{*}{ 361 } \\
\hline & $26-35$ & 47 & 4,06 & 0,46 & & \\
\hline & $36-45$ & 48 & 4,16 & 0,40 & & \\
\hline & $\geq 46$ yaş & 35 & 4,00 & 0,56 & & \\
\hline \multirow{4}{*}{ Güven } & $\leq 25$ yaş & 82 & 4,25 & 0,44 & \multirow{4}{*}{1,993} & \multirow{4}{*}{ 116 } \\
\hline & $26-35$ & 47 & 4,12 & 0,35 & & \\
\hline & $36-45$ & 48 & 4,32 & 0,38 & & \\
\hline & $\geq 46$ yaş & 35 & 4,17 & 0,54 & & \\
\hline \multirow{4}{*}{ Güvenilirlik } & $\leq 25$ yaş & 82 & 4,08 & 0,41 & \multirow{4}{*}{1,649} & \multirow{4}{*}{ 179 } \\
\hline & $26-35$ & 47 & 3,95 & 0,33 & & \\
\hline & $36-45$ & 48 & 4,05 & 0,43 & & \\
\hline & $\geq 46$ yaş & 35 & 3,89 & 0,75 & & \\
\hline \multirow{4}{*}{ Yanıt Verebilirlik } & $\leq 25$ yaş & 82 & 4,18 & 0,42 & \multirow{4}{*}{1,268} & \multirow{4}{*}{,286 } \\
\hline & $26-35$ & 47 & 4,03 & 0,54 & & \\
\hline & $36-45$ & 48 & 4,22 & 0,65 & & \\
\hline & $\geq 46$ yaş & 35 & 4,11 & 0,51 & & \\
\hline \multirow{4}{*}{ Hizmet Kalitesi } & $\leq 25$ yaş & 82 & 4,15 & 0,30 & \multirow{4}{*}{2,219} & \multirow{4}{*}{,087 } \\
\hline & $26-35$ & 47 & 4,05 & 0,30 & & \\
\hline & $36-45$ & 48 & 4,19 & 0,34 & & \\
\hline & $\geq 46$ yaş & 35 & 4,04 & 0,46 & & \\
\hline
\end{tabular}

Bireylerin eğitim düzeyi ile hizmet kalitesi ve alt boyutları arasındaki farklılığı saptamak amacıyla gerçekleştirilen ANOVA testi sonuçlarına göre, eğitim düzeyi ile ölçek ve alt boyutları arasında anlamlı farklılık bulunmamıştır. 
Tablo 7. Eğitim durumu değişkenine göre ANOVA testi sonuçları

\begin{tabular}{|c|c|c|c|c|c|c|}
\hline \multicolumn{2}{|c|}{ Eğitim Durumu } & Sayı & Ort. & S.S. & $\mathrm{F}$ & $\mathrm{p}$ \\
\hline \multirow{4}{*}{ Fiziksel Görünüm } & İlköğretim & 32 & 3,99 & 0,51 & \multirow{4}{*}{1,260} & \multirow{4}{*}{0,289} \\
\hline & Ortaöğretim & 86 & 4,14 & 0,40 & & \\
\hline & Önlisans & 35 & 4,16 & 0,40 & & \\
\hline & Lisans & 59 & 4,15 & 0,41 & & \\
\hline \multirow{4}{*}{ Empati } & İlköğretim & 32 & 4,14 & 0,48 & \multirow{4}{*}{0,184} & \multirow{4}{*}{0,907} \\
\hline & Ortaöğretim & 86 & 4,07 & 0,39 & & \\
\hline & Önlisans & 35 & 4,10 & 0,51 & & \\
\hline & Lisans & 59 & 4,08 & 0,43 & & \\
\hline \multirow{4}{*}{ Güven } & Illköğretim & 32 & 4,25 & 0,50 & \multirow{4}{*}{0,166} & \multirow{4}{*}{0,919} \\
\hline & Ortaöğretim & 86 & 4,22 & 0,43 & & \\
\hline & Önlisans & 35 & 4,25 & 0,38 & & \\
\hline & Lisans & 59 & 4,20 & 0,42 & & \\
\hline \multirow{4}{*}{ Güvenilirlik } & Ilköğretim & 32 & 3,93 & 0,60 & \multirow{4}{*}{2,469} & \multirow{4}{*}{0,063} \\
\hline & Ortaöğretim & 86 & 4,03 & 0,50 & & \\
\hline & Önlisans & 35 & 3,87 & 0,42 & & \\
\hline & Lisans & 59 & 4,12 & 0,37 & & \\
\hline \multirow{4}{*}{ Yanit Verebilirlik } & Illköğretim & 32 & 4,23 & 0,52 & \multirow{4}{*}{0,357} & \multirow{4}{*}{0,784} \\
\hline & Ortaöğretim & 86 & 4,11 & 0,46 & & \\
\hline & Önlisans & 35 & 4,15 & 0,63 & & \\
\hline & Lisans & 59 & 4,14 & 0,55 & & \\
\hline \multirow{4}{*}{ Hizmet Kalitesi } & İlköğretim & 32 & 4,10 & 0,40 & \multirow{4}{*}{0,086} & \multirow{4}{*}{0,968} \\
\hline & Ortaöğretim & 86 & 4,11 & 0,30 & & \\
\hline & Önlisans & 35 & 4,11 & 0,37 & & \\
\hline & Lisans & 59 & 4,14 & 0,35 & & \\
\hline
\end{tabular}

Çalışma kapsamında gerçekleştirilen fark analizleri sonuçlarına göre bireylerin sosyo demografik değişkenleri ile hizmet kalitesi ve alt boyutları arasında anlamlı farklılık belirlenememiştir. Buna göre, $\mathrm{H}_{2}$ hipotezi ret edilmiştir.

\section{Tartışma ve Sonuç}

Özel sağlık kuruluşundan hizmet almış bireylerin sağlık hizmetine yönelik hizmet kalite algı düzeylerini belirlemek amacıyla gerçekleştirilen çalışmanın sonuçlarına göre, bireylerin hizmet kalite algı düzeyleri yüksek olup, almış oldukları hizmete karşı pozitif bir yaklaşım göstermektedirler. Benzer şekilde, Akbolat ve meslektaşlarının (2018) hazırlamış olduğu çalışma, TEBiM'den hizmet almış 161 katılımcı üzerinde gerçekleştirilmiştir. Çalışmada kullanılan ölçeğin alt boyutları arasındaki pozitif yönlü güçlü ilişki saptanmıştır, ayrıca ölçek alt boyutlarına ilişkin kalite algısı orta düzeydedir. Beydoğan ve Kalyoncuoğlu (2017)'u Fizik Tedavi ve Rehabilitasyon Merkezi'nden yatarak veya ayaktan hizmet alan 395 hasta üzerinde yaptığı çalışmada, ölçeğin alt boyutlarına ilişkin orta düzeyde kalite algısı ve alt boyutlar arasında ilişkiler mevcuttur. Papatya ve meslektaşlarının (2012) Kırıkkale il merkezinde bulunan iki özel sağlık işletmesinde hizmet kalitesinin ve hasta memnuniyetinin karşılaştırmalı analizinin gerçekleştirildiği çalışmada da, hizmet kalite algı düzeyleri orta seviyenin üzerinde bulunmuştur. Aynı zamanda, Ceylan (2018)'ın İstanbul'da özel bir hastanede yatarak tedavi gören ve hizmet alan 240 hasta ile yapılan çalışmada da çalışmada da ölçeğe ve alt boyutlarına ilişkin hizmet kalitesi algı düzeyi ortalamanın üzerindedir. Güleş ve meslektaşlarının (2011) yapmış olduğu çalışmada ise, Konya ilinde faaliyet gösteren Kamu, Üniversite ve Özel sağlık kuruluşlarından hizmet alan hastalarla görüşmeler yapılmış olup, hizmet kalite algı düzeyleri ortalamaları her bir kuruluş için ortalamanın üzerinde bulunmuştur. Ayrıca, ölçek ve alt boyutları arasında anlamlı ilişki mevcuttur. Biçer ve meslektaşlarının (2019) hizmet kalite algısına ilişkin gerçekleştirmiş oldukları meta analiz sonuçlarına göre, hizmet kalite algısının orta düzeyde olduğu ifade etmektedir. Buna göre, çalışmanın sonuçları ile alan yazındaki çalışmalar uyumluluk göstermektedir.

Çalışmanın bir diğer sonucuna göre, bireylerin demografik değişkenleri ile hizmet kalitesi ve alt boyutları arasında anlamlı farklılıklar tespit edilmemiştir ve çalışmanın hipotezi reddedilmiştir. Bu durumda, bireylerin özel hastaneden almış oldukları hizmetin kalitesine yönelik algı düzeylerinin yüksek olduğunu, birbirleri arasında fark oluşturacak bir etmenin olmadığını söyleyebiliriz. Başka bir ifade ile özel hastane tarafından sunulan hizmetin kalitesi tüm bireyler tarafından aynı algılandığını ifade edebiliriz. Hastaların sağlık hizmetlerine ilişkin kalite algıları orta düzeyin üzerinde ise ve hastaların geneli aynı algıya sahip ise, özel hastanenin tüm hasta gruplarına orta düzeyin üzerinde kaliteli hizmet sunumunu gerçekleştirdiği ve kurumsal niteliğe kavuşturduğu söylenebilir.

Korkmaz ve Çuhadar (2017) tarafından Eğitim ve Araştırma Hastanesinde sunulan sağlık hizmet kalitesini belirlemek ve hizmet kalitesinin hastaneyi tekrar tercih etme niyeti üzerinde etkisinin olup olmadığını saptamak amacıyla hazırlamış olduklarını çalışmanın sonuçlarına göre, demografik değişkenler ile hizmet kalite algısı arasında farkııık tespit edilmemiştir. Fakat yaşın fiziksel varlıklar ve genel hizmet kalite algısı ile; cevap verebilirliğin gelir durumu ile arasında anlamlı farklılıklar belirlenmiştir. Devebakan ve Aksaraylı (2003) tarafından Özel Altınordu Hastanesinin algılanan hizmet kalite düzeyinin ölçülmesi amacıyla gerçekleștirmiş oldukları çalışmanın sonuçlarına göre, hizmet kalitesi ile bazı demografik değişkenler arasında anlamlı farklııklar saptanmıştır. Bu farklııklar; fiziksel varlıklar ile yaş; fiziksel varlıklar, güvenilirlik, empati, güven ve heveslilik ile eğitim durumu ve hizmet kalite algısı ile gelir durumu arasındadır. Bulut ve Hazar (2019)'ın Doğu Anadolu Bölgesi'nde yer alan 8 farklı ildeki kamu hastanelerinden hizmet alan 643 engelli vatandaşa uygulanmış oldukları hizmet kalite algısına yönelik çalışmada; Engelli vatandaşların yaşadıkları illere, cinsiyetlerine, yaşlarına, özel sağılı sigortası bulunma durumlarına göre hastane hizmet kalite algılarında farklılaşma saptanırken, eğitim durumlarına göre farklılaşma olmadığı belirlenmiştir. Saltık (2018)' ın ayakta ve yatarak tedavi gören hastaların sağlık hizmeti kalitesi ve alt boyutlarına ilişkin algılarının belirlenmesi amacıyla yapılmış çalışmanın sonuçlarına göre, ayakta tedavi gören hastaların sağlık hizmeti kalitesi algısının eğitim düzeyi ile doğru orantılı olduğu, buna karşın yatarak tedavi gören hastaların sağlık hizmeti kalitesinin cinsiyete, medeni duruma, eğitim durumuna, yaşa veya sosyal güvence türüne göre farklılık göstermediği belirlenmiştir. Tüm bu çalışmaların sonuçlarına göre, bireylerin sosyo demografik değişkenleri ile hizmet kalite algısı ve alt boyutlarının hepsine ilişkin farklııklar tespit edilmemiştir. Fakat bazı demografik değişkenlerin hizmet kalite algısı veya 
alt boyutlarına ilişkin farkıııklar olduğu görülmektedir. Buna göre, bireylerin hizmet aldıkları sağlık kuruluşlarına ilişkin olarak kalite algıları farklılık gösterdiğini ve sağlık kuruluşlarının ise kalite açısından tam olmadı̆̆ı söyleyebiliriz.

Sonuç olarak, özel sağlık kuruluşundan hizmet almış bireylerin demografik değişkenler ile hizmet kalite algıları ile alt boyutlarına ilişkin algıları arasında farkıııklar saptanmamıştır. Bu bulgu literatürdeki yer alan bazı çalışmalara göre farklııı oluşturmaktadır. Bu sebeple çalışmamıza katılan bireylerin almış oldukları hizmetlere ilişkin kalite algı düzeylerinin yüksek olduğunu ve bireyler arasındaki algılarını değiştirecek bir etkenin olmadığını söyleyebiliriz. Ayrıca bireyin bakış açısına göre, sağlık kuruluşunun en iyi sağlık sonuçlarına ulaşmak için kalite açısından yeterli hizmet sunduğunu ifade edebiliriz.

Yaptığımız çalışma özel sağlık kuruluşundan hizmet almış bireylerle sınırlı tutulmuştur. Gelecekte yapılacak olan çalışmaların yalnızca özel sağıık kuruluşu ile değil aynı zamanda kamu veya üniversite hastanelerinden ayaktan veya yatarak hizmet alan bireylerle yapılması önerilmektedir. Böylelikle bireylerin farkı sağılık kuruluşlarındaki hizmet kalite algılarının nasıl değiştiği gözlemlenebilir.

\section{Kaynakça}

Akbolat, M., Senai, S., \& Ünal, Ö. (2018). Hizmet kalite algısının performansa etkisi: Kocaeli Gölcük tersanesinde bir uygulama. İnsan ve Insan, 5(15), 7-20.

Beydoğan, G. Ş., \& Kalyoncuoğlu, S. (2017, October). Fizik tedavi ve rehabilitasyon hizmeti alan hastaların kalite algılarının memnuniyetleri üzerindeki etkisi: Kırşehir ilinde bir araştırma. In ICPESS (International Congress on Politic, Economic and Social Studies) (No. 2).

Biçer, D.F., Ilıman, E., \& Biçer, E. B. (2019). Sağlık kurumlarında hizmet kalite algısı üzerine meta analiz çalışması. Cumhuriyet Üniversitesi İktisadi ve ỉdari Bilimler Dergisi, 20(2), 22-47.

Boulding, W., Kalra, A., Staelin, R., \& Zeithaml, V. A. (1993). A dynamic process model of service quality: from expectations to behavioral intentions. Journal of marketing research, 30(1), 7-27.

Bulut N, \& Hazar A. (2019). An analysis of hospital service quality with regards to disabled citizens. Arch Basic Clin Res, 1(1), 16-26.

Ceylan, K. E. (2018). Sağlık sektöründe hizmet kalitesinin müşteri sadakatine etkisi: İstanbul'da özel bir hastane örneği. Yayınlanmamış Yüksek Lisans Tezi, İstanbul Gelişim Üniversitesi, Sosyal Bilimler Enstitüsü, İstanbul.

Cronin Jr, J. J., \& Taylor, S. A. (1992). Measuring service quality: a reexamination and extension. Journal of marketing, 56(3), 55-68.

Çınar, O. (2010). Okul müdürlerinin iletişim sürecindeki etkinliği, Dumlupınar Üniversitesi Sosyal Bilimler Dergisi, 62(1): 267-276.

Devebakan, N., Aksaraylı, M. (2003). Sağlık işletmelerinde algılanan hizmet kalitesinin ölçümünde Servqual skorlarının kullanımı ve Özel Altınordu Hastanesi uygulaması. Dokuz Eylül Üniversitesi Sosyal Bilimler Enstitüsü. 5(1), 38-54.

Donabedian, A. (1966). Evaluating the quality of medical care. The Milbank memorial fund quarterly, 44(3), 166-206.

Donabedian, A. (1980). Exploration in quality assesment and monitoring Volume I, The definitions of quality and approaches to its assessment, Ann Arbor, MI: Health Administration Pres, Michigan.

Güleş, H. K., Çağlıyan, V., \& Gelmez, E. (2011). Sağılık kurumlarında Servqual Ölçüm Modeli ile hizmet kalitesi ölçümü üzerine bir araştırma: Konya örneği. XI. Üretim Araştırmaları Sempozyumu, 23-24 Haziran 2011.s.319-328.

Kaya, S. (2014). Sağlık Hizmetlerinde Kalite Yönetimi. Kaya, S. (Ed.) içinde Sağlık Kurumlarında Kalite Yönetimi, Anadolu Üniversitesi Yayınları, 3. Baskı, Eskişehir.

Korkmaz, S., \& Çuhadar, U. (2017). Sağlık hizmet kalitesi ve sağlık kurumunu tekrar tercih etme niyeti arasındaki ilişki: Eğitim ve araştırma hastanesi örneği. Uluslararası Sağlık Yönetimi ve Stratejileri Araştırma Dergisi, 3(1), 72-87.

Pakdil, F., \& Harwood, T. N. (2005). Patient satisfaction in a preoperative assessment clinic: an analysis using SERVQUAL dimensions. Total Quality Management \& Business Excellence, 16(1), 15-30.

Papatya, G., Papatya, N., \& Hamşioğlu, A. B. (2012). Sağlık hizmetlerinde algılanan hizmet kalitesi ve hasta memnuniyeti: İki özel hastanede karşılaştırmalı bir araştırma. Kırıkkale Üniversitesi Sosyal Bilimler Dergisi, 2(1), 87-108.

Parasuraman, A., Zeithaml, V. A., \& Berry, L. L. (1985). A conceptual model of service quality and its implications for future research. Journal of marketing, 49(4), 41-50.

Rezaei, S., Hajizadeh, M., Zandian, H., Fathi, A., \& Nouri, B. (2018). Service quality in Iranian hospitals: A systematic review and meta-analysis. Medical journal of the Islamic Republic of Iran, 32, 59. https://doi.org/10.14196/mjiri.32.59

Saltık, S. (2018). Yatarak ve ayakta tedavi gören hastaların kalite algılarının hastane türleri üzerine araştırılması. Yayınlanmamış Yüksek Lisans Tezi, Sosyal Bilimler Enstitüsü, i̇stanbul Gelişim Üniversitesi, İstsanbul.

Sezer, C. (2018). Sağılık hizmetlerinde kalite algısı: Bir içerik analizi, 1. Uluslararası Çağdaş Eğitim ve Sosyal Bilimler Kongresi, 22-25 Kasım 2018, Antalya.

Spath, P. (2009). Introduction to Healthcare Quality Management, Health Administration Press, Chicago.

Strawderman, L., \& Koubek, R. (2006). Quality and usability in a student health clinic. International Journal of Health Care Quality Assurance, 19(3), 225-236.

Taylor, S. A., \& Cronin Jr, J. J. (1994). Modeling patient satisfaction and service quality. Journal of health care marketing, 14(1), 34-44. 